The Flowering Plants and Ferns of Great Britain : an attempt to classify them according to their Geognostic relations. By J. G. BAKER. London. 1855.

This tract is an enlarged form of a paper communicated to the British Association at its recent meeting at Glasgow. Its subject is of much interest in the study of the geographical distribution of plants, and has not received so much attention as it seems to deserve. Hitherto botanists have endeavoured to determine the causes of the migration, or creation, of the plants found in different districts, by attending to the collocation of the places where they grow, rather than from a consideration of the strata forming the crust of the earth. Mr. Baker has therefore done good service to science by this attempt at determining the geological causes that may be supposed to have had an influence. It is not to be expected that this attempt should be altogether satisfactory in its results, for many more observations than we at present possess are wanted before certain conclusions can be attained.

He arranges the strata into two great groups: (1) The dysgeogenous, "which are disintegrated with difficulty, and yield only a feeble detritus." "They absorb moisture readily, and furnish stations characterized by their comparative dryness," and contain a large proportion of carbonate of lime. And (2) the eugeogenous, "which abrade easily, and yield an abundant superficial detritus, which may be either of a sandy or clayey nature. They are comparatively impermeable, and consequently hygroscopic upon a grand scale, furnishing damper stations" than the other group. $\mathrm{He}$ then shows how these classes of strata are distributed through Great Britain, and endeavours to arrange the native plants into either those which are spread over the whole country, or confined to one or the other of the groups. We think that he has been tolerably successful, although we should not in all cases agree with him. Indeed, it seems probable that it is rather the superficial soil that must often be taken into account, than the underlying strata. The soil of large districts noted as clay on geological maps, may, and actually has, a strongly calcareous character from the presence of adjacent rocks, such as chalk, and accordingly possesses a flora containing many of the species usually called calcareous, or chalk plants, and does not produce others commonly found on a clayey soil, but which dislike the presence of lime or chalk. Mr. Baker has apparently attended solely, or chiefly, to strata, and neglected the detritus formed or deposited upon them.

Notwithstanding this objection, we have no doubt that the essay will be favourably received by botanical geographers, who find that they must consider all the causes in action, whether they be stratigraphical, detrital, geographical, or climatal.

\title{
In the Press.
}

We learn that Mr. Gosse has nearly ready a new work on the Marine Natural History of Tenby and its Vicinity. 


\section{$2 \mathrm{BHL}$ Biodiversity Heritage Library}

1856. "The flowering plants and ferns of Great Britain: an attempt to classify them according to their geognostic relations. By J. G. Baker. London. 1855." The Annals and magazine of natural history; zoology, botany, and geology 17, 199-199. https://doi.org/10.1080/00222935608697492.

View This Item Online: https://www.biodiversitylibrary.org/item/19391

DOI: https://doi.org/10.1080/00222935608697492

Permalink: https://www.biodiversitylibrary.org/partpdf/11310

\section{Holding Institution}

Natural History Museum Library, London

\section{Sponsored by}

Natural History Museum Library, London

\section{Copyright \& Reuse}

Copyright Status: Public domain. The BHL considers that this work is no longer under copyright protection.

This document was created from content at the Biodiversity Heritage Library, the world's largest open access digital library for biodiversity literature and archives. Visit BHL at https://www.biodiversitylibrary.org. 